\title{
Microsatellite Instability Overall Status
}

National Cancer Institute

\section{Source}

National Cancer Institute. Microsatellite Instability Overall Status. NCI Thesaurus. Code C139285.

The state or condition of a subject's microsatellite sequences with respect to the inability of their mismatch repair (MMR) proteins to fix a DNA replication error. 